\title{
Analisis Model Pembelajaran Two Stay Two Stray Dengan Layanan Bimbingan Kelompok Untuk Meningkatkan Komunikasi Interpersonal Siswa Di MAN Kota Palangka Raya
}

\author{
Romiaty \\ Program Studi Bimbingan Dan Konseling FKIP Univeristas Palangka Raya, \\ Kalimantan Tengah, Indonesia \\ romiaty@fkip.upr.ac.id \\ M Wahyu Maulana \\ Program Studi Bimbingan Dan Konseling FKIP Univeristas Palangka Raya, \\ Kalimantan Tengah, Indonesia \\ wahyumaulana250@gmail.com
}

\begin{abstract}
Abstrak
Tujuan dari penelitian ini adalah untuk menganalisis peningkatan kemampuan komunikasi interpersonal siswa menggunakan model pembelajaran two stay two stray dikelas X IS 1 MAN Kota Palangka Raya. Pada penelitian ini peneliti menggunakan jenis metode kualitatif dengan pendekatan penelitian lapangan (field research). Subjek dari penelitian ini adalah siswa siswi MAN Kota Palangka Raya. Dari hasil penelitian lapangan, dapat disimpulkan bahwa bahwa layanan bimbingan kelompok dengan menggunakan model pembelajaran two stay two stray dapat meningkatkan kemampuan komunikasi interpersonal siswa di MAN Kota Palangka Raya.
\end{abstract}

Kata kunci: Two Stay Two Stray, Layanan Bimbingan Kelompok, Komunikasi Interpersonal

\section{Abstract}

Analysis of the Two Stay Two Stray Learning Model with Group Guidance Services to Improve Interpersonal Communication of Students in MAN Palangka Raya City. The purpose of this study was to analyze the improvement of students' interpersonal communication skills using the two stay two stray learning model in class X IS 1 MAN Kota Palangka Raya. In this study, researchers used a qualitative 
method with a field research approach. The subjects of this study were students of MAN Palangka Raya City. From the results of field research, it can be concluded that group guidance services using the two stay two stray learning model can improve students' interpersonal communication skills in MAN Kota Palangka Raya.

Keywords: Two Stay Two Stray, Group Guidance Service, Interpersonal Communication

\section{A. Pendahuluan}

Komunikasi merupakan kebutuhan setiap manusia, khususnya dalam menjalin interaksi kemanusiaan dan memenuhi kebutuhan hidup manusia. Pola komunikasi yang berkembang tidak hanya bersifat informatif tetapi juga persuasif. Artinya komunikasi tidak hanya bertujuan agar orang lain mengerti, tetapi juga berharap agar orang lain menerima suatu paham keyakinan atau melakukan suatu perbuatan tertentu (Effendi, 1996: 9).

Komunikasi yang dilakukan pada dasarnya memiliki empat fungsi yaitu fungsi sosial, ekspresif, ritual dan instrumental. Diantara fungsi komunikasi tersebut nampaknya tidak sama sekali independen, melainkan saling berkaitan satu dengan lainnya, meskipun terdapat fungsi komunikasi yang dominan, salah satunya adalah fungsi sosial untuk membangun konsep diri, aktualisasi diri, untuk kelangsungan hidup, memperoleh kebahagiaan, terhindar dari tekanan dan ketegangan serta memupuk hubungan dengan orang lain (Mulyana, 2002: 5). Dalam menjalin interaksi dengan orang lain, komunikasi dikatakan efektif apabila ditandai dengan hubungan interpersonal yang baik. Sedangkan kegagalan komunikasi terjadi apabila isi pesan kita dipahami orang, tetapi juga pada hubungan diantara pelaku komunikasi itu sendiri.

Hubungan komunikasi ini merupakan bentuk komunikasi interpersonal. Komunikasi interpersonal merupakan salah satu bentuk komunikasi yang sering dilakukan, menurut Gerald R Miller (1989) komunikasi interpersonal merupakan jenis komunikasi yang terjalin secara harmonis dimana masingmasing pelaku komunikasi dapat bertindak sebagai komunikator mapun komunikan secara 
bergantian dan dilingkupi dinamika psikologis yang begitu mendalam secara face to face (Rahmad, 2000: 119). Tujuan penting komunikasi interpersonal diarahkan pada enam hal yaitu mengenal diri sendiri dan orang lain, mengetahui dunia luar, menciptakan dan memelihara hubungan, mengubah sikap dan perilaku, mencari hiburan dan membantu orang lain.

Menurut Joseph N Cappella (1963) dalam Gerald R Miller disebutkan bahwa komunikasi interpersonal yang dilakukan pada tingkatan tertentu dapat melahirkan suasana dan dinamika psikologis yang dapat memberikan manfaat pada kebutuhan psiko-emosional manusia (Miller, 1989: 59). Kebutuhan psikoemosional tersebut meliputi adanya perasaan keterbukaan, empati, sikap suportif, sikap positif dan kesetaraan, cinta, kasih sayang, penghargaan, ketenangan dan kepercayaan (Kafie, 1993: 121). Lebih lanjut dijelaskan bahwa manusia secara psikis memiliki kecenderungan terhambatnya kebutuhan psiko-emosional yang mengakibatkan dirinya mengalami tekanan emosi yang berupa kecemasan, prasangka, rasa takut, khawatir dan was-was, marah, agresif dan anarkis.

Komunikasi merupakan aktivitas dasar manusia, dengan berkomunikasi manusia dapat berhubungan satu sama lain dalam kehidupan sehari-hari dimanapun manusia itu berada. Komunikasi juga merupakan hal yang sangat vital dalam keberlangsungan dan keberhasilan sebuah interaksi, baik dalam lingkungan formal semisal organisasi/lembaga pendidikan maupun pada tataran interaksi pada organisasi yang bersifat umum.

Dalan hal ini komunikasi yang efektif akan sangat menentukan keberhasilan sebuah interaksi, serta kelangsungan hidup peserta didik. Pentingnya komunikasi bagi manusia tidaklah dapat dipungkiri begitu juga halnya bagi peserta didik. Dengan adanya komunikasi yang baik hubungan antar peserta didik dapat berjalan dengan lancar dan berhasil dan begitu juga sebalikmya, kurangnya atau tidak adanya komunikasi antar peserta didik hubunga dapat macet atau berantakan.

Komunikasi adalah sebuah tindakan untuk berbagi informasi, gagasan, atau pendapat dari setiap partisipan komunikasi yang terlibat di dalamnya guna 
mencapai kesamaan makna. Tindak komunikasi tersebut dapat dilakukan dalam beragam konteks, antara lain adalah dalam lingkup organisasi (organizational communication) (Wijaya, 2013). Dalam Al-Qur'an sendiri telah dijelaskan tentang pentingnya komunikasi dalam organisasi terutama ketika mengambil keputusan dalam setiap permasalahan yang bisa dilakukan melalui musyawarah, seperti firman Allah dalam QS. Asy-Syu'ara(42): 38 yang artinya: Dan (bagi) orang-orang yang menerima (mematuhi) seruan Tuhannya dan mendirikan shalat, sedang urusan mereka (diputuskan) dengan musyawarat antara mereka; dan mereka menafkahkan sebagian dari rezki yang Kami berikan kepada mereka.

Berdasarkan hasil observasi dan wawancara yang dilakukan pada saat PPL Bimbingan mendapatkan hasil bahwa banyak siswa yang memiliki komunikasi interpersonal yang rendah di MAN Kota Palangka Raya. Siswa kelas X IS 1 MAN Kota Palangka Raya banyak mengalami masalah dalam komunikasi interpersonal, berdasarkan kurangnya kemampuan komunikasi interpersonalnya, dapat diuraikan sebagai berikut : 1) Terdapat 3 orang siswa yang mengalami kurangnya keterbukaan, seperti sering membicarakan keburukan teman sekelasnya, 2) Terdapat 2 orang siswa yang mengalami kurangnya empati, seperti sering membuat kegaduhan didalam kelas sehingga menggangu orang lain, 3) Terdapat 3 orang siswa yang mengalami kurangnya dukungan, seperti sifat iri yang diiringi dengan sikap ketidaksukaan terhadap sesuatu atau seseorang. Perlu adanya bimbingan kelompok untuk meningkatkan keterampilan komunikasi interpersonal siswa.

\section{B. Pembahasan}

\section{Komunikasi Interpersonal}

Secara kontekstual komunikasi interpersonal digambarkan sebagai suatu komunikasi antara dua individu atau sedikit individu yang mana saling berinteraksi, saling memberikan umpan balik satu sama lain. Namun, memberikan definisi kontekstual saja tidak cukup untuk menggambarkan komunikasi interpersonal karena setiap interaksi antara satu individu dengan 
individu lain berbeda-beda. Mulyana (Rico, Fitriana, \& Lestari, 2012) menyatakan bahwa komunikasi interpersonal ini adalah komunikasi yang hanya dua orang, seperti suami istri , dua sejawat, dua sahabat dekat, gurumurid dan sebagainya.

Hal tersebut dapat dimengerti karena komunikasi interpersonal adalah hubungan interaksi diantara dua orang atau lebih, dalam komunikasi ini yang terjadi adalah komunikasi timbal balik atau dua arah. Selain itu dalam komunikasi kita dengan orang lain yang dapat disampaikan tidak hanya isi pesan saja, tetapi yang terjadi juga dapat menentukan keadaan dan kedalaman suatu hubungan. Didalam kehidupan kita masing-masing kita pasti melakukan komunikasi, baik komunikasi kita dengan Orang tua, saudara, atau dengan sahabat, pastinya setiap komunikasi itu memiliki makna dan kedalaman masing-masing. Terlebih lagi dalam lingkungan sekolah, khususnya dengan teman-teman yang berada dalam lingkungan sekolah tersebut. Sebagai makhluk sosial, siswa senantiasa melakukan interaksi sosial dengan orang lain. Interaksi sosial menjadi faktor utama dalam komunikasi interpersonal antara dua orang atau lebih yang saling mempengaruhi. Seiring dengan perkembangan lingkungan sosial seseorang, interaksi sosial meliputi lingkungan sosial yang luas, seperti sekolah dengan teman-teman.

Menurut DeVito (Fajar, 2009: 84-86) tentang ciri-ciri komunikasi sebagai berikut, 1) Kurangnya Keterbukaan, yaitu kemampuan menanggapi dengan senang hati informasi yang diterima didalam menghadapi hubungan antar pribadi, 2) Empati, yaitu merasakan apa yang dirasakan orang lain, 3) Dukungan, yaitu situasi yang terbuka untuk mendukung komunikasi berlangsung efektif, 4) Perilaku Positif, yaitu seorang harus memiliki perasaan positif terhadap dirinya, mendorong orang lain lebih aktif berpartisipasi, dan menciptakan situasi komunikasi kondusif untuk interaksi yang efektif, 5) Kesetaraan atau Kesamaan, yaitu pengakuan secara diam-diam bahwa kedua belah pihak menghargai, berguna dan mempunyai sesuatu yang penting untuk 
disumbangkan, 6) Kebersamaan, yaitu seseorang bisa meningkatkan efektivitas komunikasi antar pribadi dengan orang lain bila ia bisa membawa rasa kebersamaan.

\section{Layanan Bimbingan Kelompok}

Istilah bimbingan selalu dirangkaikan dengan istilah konseling. Hal ini disebabkan karena bimbingan dan konseling itu merupakan suatu kegiatan yang integral (utuh atau melengkapi). Konseling merupakan salah satu teknik dalam pelayanan bimbingan diantara beberapa teknik lainnya. Bimbingan itu lebih luas dan konseling merupakan alat yang paling penting dari usaha pelayanan bimbingan. Konseling merupakan satu pertalian timbal balik antara individu dalam memecahkan masalah kehidupannya untuk mencapai kesejahteraan hidupnya secara optimal.Jadi bimbingan menyangkut konseling dan sebaliknya konseling juga menyangkut bimbingan. Namun konseling disini diberikan secara kelompok seperti: bimbingan pada umumnya bagaimana cara belajar yang efesien dan dapat diberikan kepada seluruh kelas pada suatu waktu tertentu secara bersama-sama. Dari uraian-uraian dan teori-teori yang telah dikemukakan di atas maka dapatlah ditarik suatu kesimpulan yang efektif yaitu sebagai berikut: bimbingan konseling adalah suatu proses pemberian bantuan secara terus-menerus dalam perkembangan individual untuk mencapai kemampuan, pemahaman dan pengarahan diri, penyesuaian diri serta pemecahan masalah yang dihadapi, sehingga dapat bertindak wajar sesuai dengan tuntutan lingkungannya (Bastomi, 2020).

Proses Bimbingan dan Konseling di sekolah dapat berhasil apabila mempunyai tujuan yang jelas yang akan dicapainya.Bimbingan dan konseling bertujuan untuk membantu peserta didik agar dapat mencapai tujuan-tujuan perkembangannya yang meliputi aspek pribadi-sosial belajar (akademik) dan karir (Nurihsan \& Yusuf, 2010, p. 15). 
Prayitno (2009: 57) menjelaskan bahwa layanan bimbingan kelompok merupakan proses pemberian informasi dan bantuan pada sekelompok orang dengan memanfaatkan dinamika kelompok guna untuk mencapai suatu tujuan tertentu. Sejalan dengan itu, Rusmana (Hidayati, 2013) mendefinisikan bimbingan kelompok sebagai: Proses pemberian bantuan kepada individu melalui suasana kelompok yang memungkinkan setiap anggota untuk berpartisipasi aktif dalam upaya pengembangan wawasan, sikap dan atau keterampilan yang diperlukan dalam upaya mencegah timbulnya masalah atau dalam upaya pengembangan pribadi.

Menurut Winkel (2005: 68), tujuan bimbingan kelompok ada tiga yaitu: 1.Supaya orang yang dilayani mampu mengatur kehidupannya sendiri. 2. Memiliki pandangan sendiri dan tidak hanya sekedar "membebek" pendapat orang lain. 3. Mengambil sikap sendiri dan berani menanggung sendiri konsekuensi-konsekuensi dari tindakannya. Adapun mengenai tujuan dalam kegiatan bimbingan, ditetapkan berdasarkan permasalahan yang dialami oleh konseli serta pendekatan bimbingan yang dilakukan oleh konselor.

\section{Model Pembelajaran Kooperatif tipe Two Stay Two Stray}

Model Pembelajaran Kooperatif tipe Two Stay Two Stray dikembangkan oleh Kagan (Suprijono, 2010: 93). Metode ini biasa digunakan dalam semua mata pelajaran dan untuk semua tingkatan usia peserta didik. Metode TS-TS merupakan sistem pembelajaran kelompok dengan tujuan agar siswa dapat saling bekerja sama, bertanggung jawab, saling membantu memecahkan masalah, dan saling mendorong satu sama lain untuk berprestasi. Metode ini juga melatih siswa untuk bersosialisasi dengan baik.

Langkah-langkah model pembelajaran TS-TS menurut Suprijono (2010: 93) dapat dilihat pada rincian tahap tahap berikut ini :

a. Guru membagi siswa dalam beberapa kelompok yang setiap kelompoknya terdiri dari empat siswa. Kelompok yang dibentuk pun merupakan 
kelompok heterogen, misalnya satu kelompok terdiri dari 1 siswa berkemampuan tinggi, 2 siswa berkemampuan sedang, dan 1 siswa berkemampuan rendah. Hal ini dilakukan karena pembelajaran kooperatif tipe TS-TS bertujuan untuk memberikan kesempatan pada siswa untuk saling membelajarkan ( peer tutoring ) dan saling mendukung.

b. Guru memberikan subpokok bahasan pada tiap - tiap kelompok untuk dibahas bersama - sama dengan anggota kelompok masing - masing.

c. Siswa bekerja sama dalam kelompok yang beranggotakan empat orang. Hal ini bertujuan untuk memberikan kesempatan kepada siswa untuk dapat terlibat secara aktif dalam proses berpikir.

d. Setelah selesai, dua orang masing - masing kelompok meninggalkan kelompoknya untuk bertamu ke kelompok lain.

e. Dua orang yang tinggal dalam kelompok bertugas membagikan hasil kerja dan informasi mereka kepada tamu dari kelompok lain.

f. Tamu mohon diri dan kembali ke kelompok mereka sendiri untuk melaporkan temuan mereka dari kelompok lain.

g. Kelompok mencocokan dan membahas hasil - hasil kerja mereka.

h. Masing - masing kelompok mempresentasikan hasil kerja mereka.

\section{Metode}

Dalam Penelitian ini mengunakan Metode Riset Lapangan field research) dengan teknik analisis deskriptif kualitatif. Data penelitian yang terkumpul kemudian dianalisis dengan menggunakan pendekatan deduktif dan pendekatan induktif. Metode deduktif yaitu metode pembahasan dengan menggunakan pola pikir yang berangkat dari pengetahuan yang sifatnya umum, kepada penilain yang bersifat khusus yang berkenaan dengan model pembelajaran two stay two stray dengan layanan bimbingan kelompok untuk meningkatkan komunikasi interpersonal siswa di MAN Kota Palangka Raya. Sedangkan metode induktif yaitu suatu pengambilan keputusan dengan 
menggunakan pola pikir yang berangkat dari fakta-fakta yang sifatnya khusus kemudian digeneralisasikan kepada hal-hal yang bersifat umum mengenai model pembelajaran two stay two stray dengan layanan bimbingan kelompok untuk meningkatkan komunikasi interpersonal siswa di MAN Kota Palangka Raya.

\section{Hasil dan Pembahasan}

Disini peneliti mendapatkan kurangnya kemampuan komunikasi interpersonal siswa berdasarka hasil observasi dilapangan saat melakukan PPL bimbingan di MAN Kota Palangka Raya. Secara kodrati manusia akan selalu hidup bersama. Hidup bersama antara manusia akan berlangsung dalam berbagai bentuk komunikasi dan situasi. Dalam kehidupan semacam inilah terjadi interaksi. Dengan demikian, kegiatan hidup manusia akan selalu dibarengi dengan proses interaksi arau komunikasi, baik interaksi dengan alam lingkungan, interaksi dengan sesamanya, maupun interaksi dengan Tuhan-Nya, baik itu disengaja maupun tidak disengaja (Arifin, 2015: 19-27).

Komunikasi interpersonal secara umum terjadi di antara dua orang. Seluruh proses komunikasi terjadi di antara beberapa orang, namun banyak interaksi tidak melibatkan seluruh orang di dalamnya secara akrab. Proses komunikasi interpersonal menggambarkan terjadinya kegiatan komunikasi sebagai proses yang menghubungkan pengirim dengan penerima pesan. Dalam proses komunikasi interpersonal, komunikator memiliki peranan penting menentukan keberhasilan dalam mempengaruhi komunikan, berkaitan erat dengan karakter yang melekat pada komunikator itu sendiri. Asumsi tersebut didasarkan pada pendapat bahwa karakteristik komunikator yang mencakup keahlian atau kredibilitas, daya tarik dan keterpercayaan, merupakan faktor yang sangat berpengaruh dan menentukan keberhasilan komunikator melaksanakan komunikasi (Kurniati, 2012: 14). 
Komunikasi interpersonal merupakan komunikasi yang mempunyai efek besar dalam hal mempengaruhi orang lain terutama perindividu. Hal ini disebabkan, biasanya pihak-pihak yang terlibat dalam komunikasi bertemu secara langsung, tidak menggunakan media dalam penyampaian pesannya sehingga tidak ada jarak yang memisahkan antara komunikator dengan komunikan (face to face). Oleh karena saling berhadapan muka, maka masingmasing pihak dapat langsung mengetahui respon yang diberikan, serta mengurangi tingkat ketidakjujuran ketika sedang terjadi komunikasi (Siswandini, 2015).

Ada beberapa ciri-ciri komunikasi interpersonal menurut DeVito seperti; keterbukaan, empati, dukungan, rasa positif, dan kesetaraan. Menurut Hidayat (2013: 132) "TSTS yaitu salah satu tipe pembelajaran kooperatif yang memberikan kesempatan kepada kelompok membagikan hasil dan informasi kepada kelompok lain. Hal ini dilakukan dengan cara saling mengunjungi atau bertemu antar kelompok untuk berbagai informasi". Dalam proses pembelajaran dengan menggunakan model TSTS, secara sadar ataupun tidak siswa akan melakukan kegiatan menyimak dan berbicara, dimana hal ini akan mendorong keaktifan siswa.

Model pembelajaran two stay two stray atau sering juga disebut dengan dua tinggal dua tamu adalah salah satu model pembelajaran kelompok dimana setiap kelompoknya terdiri dari empat orang, dalam pelaksanaannya dua orang dari setiap kelompok harus bertamu ke kelompok lain serta dua orang lagi tetap tinggal di kelompoknya untuk menerima tamu dari kelompok lain (Winarti, Fatirul, \& Hartono, 2020).

Pelaksanaan teknik two stay two stray membuat siswa merasa lebih mudah membicarakan topik/persoalan yang mereka hadapi kepada kelompok sebayanya, dimana mereka akan lebih leluasa bergaul dan saling terbuka didalam bentuk diskusi yang dan akrab, sehingga bertukar pikiran, pendapat 
dan pengalam yang nantinya akan bermanfaat bagi mereka sendiri (Arifin, 2015: 25).

Metode two stay two stray atau "dua tinggal dua tamu" dikembangkan oleh Spencer kagan pada tahun 1992. Metode pembelajaran kooperatif ini dapat digunakan pada semua mata pelajaran dalam semua jenjang pendidikan atau semua tingkatan usia pembelajar (Lie, 2002: 44).

Menurut Rifaldi (2010: 42-47), beberapa cara penerapan model pembelajaran two stay two stray sebagai berikut : Kerja kelompok secara heterogen. Setelah selesai, dua siswa dari masing-masing kelompok bertamu ke kelompok lain. Dua orang yang tinggal dalam kelomppok bertugas membagikan hasil kerja dan informasi ke tamu mereka dari kelompok lain. Tamu mohon diri dan kembali kekelompok mererka sendiri dengan melaporkan temuan mereka dari kelompok lain. Kelompok mencocokan dan membahas hasil-hasil kerja mereka.

Pada sub-bab pembahasan ini akan dibahas berbagai hal yang menjadi temuan penelitian ini yang kemudian akan dijadikan sebagai bahan untuk menjawab pertanyaan dari rumusan masalah dan menarik kesimpulan. Dalam proses mengkaji kepustakaan tentang model pembelajaran two stay two stray untuk meningkatkan kemampuan komunikasi siswa, peneliti menemui beberapa kendala yakni literatur yang diperlukan sulit untuk ditemukan, sumber kajian yang digunakan kebanyakan mengutarakan hal yang bersifat tersirat sehingga membuat pembahsan kurang mendalam. Oleh karena itu dalam pembahasan kajian dalam sub bab yang ada, peneliti mengambil dari penjelasan yang ada, baik yang tersurat maupun tersirat.

a. Berdasarkan pada hasil observasi dan wawancara sebelumnya, terdapat beberapa siswa yang memiliki kurang nya komunikasi interpersonalnya, dengan mengacu pada teori De Vito dapat diuraikan sebagai berikut : 1) Terdapat 3 orang siswa yang mengalami kurangnya keterbukaan, seperti sering membicarakan keburukan teman sekelasnya, 2) Terdapat 2 orang 
siswa yang mengalami kurangnya empati, seperti sering membuat kegaduhan didalam kelas sehingga menggangu orang lain, 3) Terdapat 3 orang siswa yang mengalami kurangnya dukungan, seperti sifat iri yang diiringi dengan sikap ketidak sukaan terhadap sesuatu atau seseorang.

b. Disini peneliti menggunakan layanan bimbingan kelompok untuk meningkatkan komunikasi interpersonal siswa, layanan bimbingan kelompok dapat membantu proses kegiata berlangsung berdasarkan teori Prayitno (2009: 87) menjelaskan bahwa layanan bimbingan kelompok merupakan proses pemberian informasi dan bantuan pada sekelompok orang dengan memanfaatkan dinamika kelompok guna untuk mencapai suatu tujuan tertentu. Dan bimbingan kelompok ialah Proses pemberian bantuan kepada individu melalui suasana kelompok yang memungkinkan setiap anggota untuk berpartisipasi aktif dalam upaya pengembangan wawasan, sikap dan atau keterampilan yang diperlukan dalam upaya mencegah timbulnya masalah atau dalam upaya pengembangan pribadi (Hidayati, 2013)

c. Model pembelajaran yang digunakan dalam penelitian ini ialah model pembelajaran two stay two stray . Suprijono (Anggraeni, 2014: 93) model ini biasa digunakan dalam semua mata pelajaran dan untuk semua tingkatan usia peserta didik. Model TS-TS merupakan sistem pembelajaran kelompok dengan tujuan agar siswa dapat saling bekerja sama, bertanggung jawab , saling membantu memecahkan masalah, dan saling mendorong satu sama lain untuk berprestasi. Model ini juga melatih siswa untuk bersosialisasi dengan baik.

Dengan menggunakan model pembelajaran two stay two stray dari beberapa kajian/ teori yang telah digunakan oleh penelitian terdahulu, bahwa model pembelajaran two stay two stray dapat meningkatkan komunikasi interpersonal siswa. Sehinggga model pembelajaran tersebut dapat digunakan untuk meningkatkan kemampuan komunikasi interpersonal siswa di MAN Kota Palangka Raya. 


\section{Simpulan}

Berdasarkan pengamatan lapangan yang dilakukan peneliti bahwa layanan bimbingan kelompok dengan menggunakan model pembelajaran two stay two stray dapat meningkatkan kemampuan komunikasi interpersonal siswa di MAN Kota Palangka Raya. Metode ini biasa digunakan dalam semua mata pelajaran termasuk dalam bimbingan kelompok dan untuk semua tingkatan usia peserta didik. Metode TS-TS merupakan sistem pembelajaran kelompok dengan tujuan agar siswa dapat saling bekerja sama, bertanggung jawab, saling membantu memecahkan masalah, dan saling mendorong satu sama lain untuk berprestasi. Metode ini juga melatih siswa untuk bersosialisasi dengan baik. 


\section{DAFTAR PUSTAKA}

Anggraeni, S. (2014). Anggraeni, S. (2014). Penerapan Model Pembelajaran Kooperatif Tipe Tgt (Teams Games Tournament) Untuk Meningkatkan Keaktifan Dan Prestasi Belajar Sosiologi Pada Siswa Kelas X IIS 4 SMA batik 1 Surakarta Tahun Pelajaran 2014/2015 (Universitas Negeri Sebelas Maret). Universitas Negeri Sebelas Maret. Retrieved from https://eprints.uns.ac.id/23403/

Arifin, A. A. (2015). Teknik Two Stay Two Stray Dalam Bimbingan Kelompok Untuk Meningkatkan Wawasan Siswa Dalam Pemilihan Jurusan Di Perguruan Tinggi Negeri. FKIP Universitas Khairun Maluku Utara.

Bastomi, H. (2020). Pemetaan Masalah Belajar Siswa SMK Negeri 3 Yogyakarta Dan Penyelesaiannya (Tinjauan Srata Kelas). KONSELING EDUKASI: Journal of Guidance And Counseling, 4 No. 1.

Effendi, O. U. (1996). Ilmu Komunikas: Teori Komunikasi dan Praktek. Bandung: Rosdakarya.

Fajar, M. (2009). Ilmu Komunikasi Teori dan Praktek. Yogyakarta: Graha Ilmu.

Hidayat, A. K. (2013). Aplikasi Pembelajaran Materi Dasar Taman KanakKanak Berbasis Android. Jurnal Transit, 1 (3).

Hidayati, R. (2013). Model Bimbingan Kelompok Dengan Teknik Stimulus Control Untuk Meningkatkan Kemandirian Belajar Siswa. Jurnal Bimbingan Konseling, 2 (2).

Kafie, J. (1993). Psikologi Dakwah. Surabaya: Indah Offset.

Kurniati, R. (2012). Pengaruh Model Pembelajaran Cooperative Learning Teknik Two Stay Two Stray (Dua Tinggal Dua Bertamu) Terhadap Hasil Belajar Siswa Pada Mata Pelajaran Ekonomi. Universitas Pendidikan Indonesia Bandung.

Lie, A. (2002). Mempraktikkan Cooperative Learning di Ruang-Ruang Kelas. Jakarta: Gasindo.

Miller, G. R. . (1989). Exploration in Interpersonal Communication. London: SAGA Publications.

Mulyana, D. (2002). Ilmu Komunikasi. Bandung: Rosdakarya.

Nurihsan, J., \& Yusuf, S. (2010). Landasan Bimbingan dan Konseling. Bandung: Remaja Rosdakarya.

Prayitno, \& Amti, E. (2009). Dasar-Dasar Bimbingan Dan Konseling. Jakarta: Rineka Cipta.

Rahmad, J. (2000). Psikologi Komunikasi. Bandung: Rosdakarya.

Rico, D. M. P., Fitriana, S., \& Lestari, F. W. (2012). Metode Two Stay Two Stray 
Untuk Meningkatkan Kemampuan Komunikasi Interpersonal. JGK (JURNAL GURU KITA), 4 (1).

Rifaldi, A. M. (2010). Penerapan Pembelajaran Kooperatif Model Two Stay Two Stray (TSTS) Untuk Meningkatkan Aspek Kognitif dan Aspek Afektif Siswa Kelas X.5 SMA Negeri 02 Junrejo, Kota Batu. Universitas Negeri Malang.

Siswandini, R. (2015). IMPLEMENTASI BLENDED LEARNING UNTUK MENINGKATKAN KREATIVITAS DAN HASIL BELAJAR PADA MATA PELAJARAN EKONOMI PESERTA DIDIK KELAS XI IPS-2 SMAN 5 JEMBER SEMESTER GASAL TAHUN 2015/2016. JPE : Jurnal Pendidikan Ekonomi, 9 (2).

Suprijono, A. (2010). Cooperative Learning. Yogyakarta: Pustaka Media.

Wijaya, I. S. (2013). Komunikasi Interpersonal Dan Iklim Komunikasi Dalam Organisasi. Jurnal Dakwah Tabligh, 14, No. 1, 115-126.

Winarti, T., Fatirul, A. N., \& Hartono. (2020). Model Pembelajaran Problem Based Learning, Inkuiri Terbimbing, dan Learing Creativity Berpengaruh Terhadap Prestasi Belajar Matematika. JURNAL PEDAGOGI DAN PEMBELAJARAN, 3 (3).

Winkel, W. S., \& Hastuti, M. M. S. (2005). Bimbingan dan konseling di institusi pendidikan. Yogyakarta: Media Abadi. 